\title{
A Comparative Analysis of Competency Expectations between Tourism Professionals and Tourism Academicians
}

Nagarjuna $G^{*}$

\section{Abstract}

Education is one of the strongest foundations which enable an individual to develop his competency and skills. Education also helps in making positive contributions towards the creation of wealth and quality of life. Educational institutions transform the life of the individual and also makes him contributeto the welfare of the society and organization he or she works for. The organization looks for those candidates who can contribute to the growth and development of the organization through his or her ability and skills. Education institution has to develop skills and abilities among the students which meet the competency expectations of the organization. The purpose of the study is to investigate whether tourism education meets the competency expectation of the tourism industry. The main objective of this study is to find out the gap between competency expectations of tourism academicians and tourism professionals. The scope of the study covers institutions which offer tourism education in Bangalore, Shimoga, and Mangalore. The study also includes service sectors such as travel agencies and tour operators, hotels and airlines within Bangalore. The targeted respondents of the study are tourism faculty members of institutions and tourism professionals in service organizations. Both

* Assistant Professor, Department of Travel and Tourism, Mount Carmel College, Bangalore, India; nagarjun.arjun82@gmail.com 
primary and secondary data are considered to collect the data. Statistical tools such as correlation, paired sample test are used to analyse the data. The study found that there is a gap that exists between perception of academicians and tourism professionals on the benefit of tourism degrees and also insisted more relevant curriculum that meets the needs of the industry. This study also suggested various measures that would help education institutions to meet the expectations of industry by providing skilled workforce.

Keywords: Competency, Tourism, Education, Skills

\section{Introduction}

The first tourism course in the country was started in 1972 at the undergraduate level by the College of Vocational Studies, University of Delhi. Specific skill requirements of the sector, such as airline ticketing and tour guiding programmes were organized by airlines and the Government tourism departments from time to time. In the year 1983, Indian Institute of Tourism and Travel Management (IITTM) was established by the Central Ministry of Tourism, as the apex body for tourism education in the country. By 1989, IITTM started expanding its activities by setting up regional chapters at Bombay and Trivandrum and offering its management development programmes in tourism, leading to a Diploma in Tourism Management. The IITTM now has regional chapters in Bhubaneswar, Calcutta, Goa, Lucknow and Trivandrum. IITTM offers Diploma courses and a variety of training programmes at Gwalior and its other regional offices. IITTM offered assistance in curriculum design, especially for the Mater Level Programmes in Tourism Administration (MTA), which was started in 1991 in Kurukshetra University and lobbying with University Grant Commission (UGC), which resulted in the UGC financing introduction of tourism courses in institutions all over the country (Jithendran\& Baum, 2000).

When tourism became an important source of economic growth which required skilled human resources, it influenced many universities and colleges to start tourism courses from Certificate level to Doctoral level. Colleges affiliated to Universities and 
University Departments offer undergraduate and post-graduate programmes. Vocational higher secondary schools and technical training institutes are mainly offering certificate and diploma level programmes. The selection and eligibility criteria for tourism courses may vary from one tourism institute to another. One has to complete higher secondary education to meet the eligibility criterion for admission in travel and tourism courses at the undergraduate levels. The most common post-graduate degree awarded is Master of Tourism Administration (MTA) which is a two-year full-time programme (Kuruvilla, Moira, Jacob, Mylonopoulos, Kuruvilla, \&Weng, 2011).

\section{Human Capital in Tourism Sector}

The travel and tourism sector is one of the biggest employment generators and is currently employing 31 million people which is expected to rise to 40 million by 2019 and 43 million by 2022 (NSDC, 2009). 42-45\% of people are diploma or certificate holders, and $25-30 \%$ are graduates and post graduates (NSDC, 2009). The functional areas include ticketing, travel counselling, marketing and sales, finance department, foreign exchange, etc. To work in these areas, it is essential to have necessary skills such as communication skill, interpersonal skills, knowledge of product, knowledge of various destinations, technical skill, etc. These skills help in achieving the growth of tourism sector. The overall employment by 2022 in the Tourism Industry (in Hotels and Restaurants and Tour Operators) is estimated to be about 7.2 million. The employment in the hotel category (excluding motels along the highway) is forecasted to increase to over 1.9 million in 2012, 2.9 million by 2018 and 4 million in 2022. The incremental human resource requirement in the Restaurants category is estimated to be around0.72 million. Group tours, ticketing, and accounts are the key functions of travel agencies and tour operators, and these accounts to $55 \%$ of all the employees in this sector. The tourism sector employs a substantial number of casual workers (to the extent of 20\%).In 2008, travel trade employed 0.13 million people, and the number grew to 0.16 million by 2012. It is estimated to grow to 0.22 million by 2018. Travel trade is estimated 
to employ 0.3 million by 2022 , leading to an incremental human resource requirement of 0.14 million (NSDC, 2009).

\section{Tourism educational competencies}

Tourism educational competency is nothing but, the ability in providing quality and skilled human resources to meet the expectations and requirements of the tourism industry. According to the WTO tourism education system, it must assure its competitiveness by considering the following principles

1. The education system during its educational process has to consider the skill which matches the real expectations and needs of demand (external and internal consumers)

2. Tourism education has to adapt according to changing requirements of the tourism industry and has to provide the right kind of training to the human resources

3. Tourism education has to develop competencies in the individual by considering tourism sector requirements (WTO, 2004)

\section{Educational institutions as a source of recruitment for tourism industry}

Association of Tourism Trade Organizations, India (ATTOI) has come out with various measures to create awareness about tourism opportunities and its growth from the school level. Further, it will help students with a flair for the tourism industry to opt for higher studies with the help of educational institutions. A well-educated and trained workforce is necessary for the tourism industry to ensure quality service. ATTOI also encourages tourism education by providing accreditation to institutions (ATTOI). Tourism organizations also look for candidates who have completed their course in tourism; for instance, SOTC in the career column of their website mentioned the qualifications required for the post of Senior Manager Sales as graduates, diploma/PG in travel and tourism management. On similar lines, Cox \& Kings also advertised opportunities for graduates and IATA qualified for their job requirements. 


\section{Tourism industry in India}

Tourism is one of the biggest service sectors in India. There will be a $7.7 \%$ of contribution to the National Gross Domestic Product between the period 2013-2022 and it also contributes $1.6 \%$ of the total employment (Travel and Tourism Competitiveness Report, 2013). Approximately more than 5 million foreign tourists and also 562 million domestic tourists visit India in a year. The tourism sector in India has generated about US\$100 billion in 2008, and that is expected to increase to US $\$ 275.5$ billion by 2018 at a $9.4 \%$ annual growth rate. According to World Travel and Tourism Council, India will be a tourism hotspot from 2009-2018, having the highest ten-year growth potential (Lalnunmawia, 2013). So considering the above facts and figures, it is necessary to maintain the quality and demand to remain competitive. To meet the quality and demand, the tourism industry requires skilled human resources.

Tourism is a service oriented industry and it is also called as the people industry. The major functioning of tourism sector depends on its human resources. The quality of human resource is very important for the success of the tourism business. For the development of human capital, tourism education plays a vital role and this further contributes to the success of tourism business, which leads to the economic development of the tourism sector. Tourism education is considered as one of the sub-sectors of tourism and could impact the tourism sector.

\section{Review of Literature}

The industry requires youngsters who are skilled and ready to meet its growing demands. They must also be ready to face global competition but in reality, it is not happening. A skilled workforce is required for a strong, sustainable and balanced growth. Both soft skills and job competencies are essential to make a good impression during job interviews, but the current young workforce does not possess such soft skills. Soft skills such as time management, written communication, personal skills, stress management and transferable skills such as the capability to deal with the internal politics of the industrial organization and the ability to sell oneself 
have to be considered while formulating the tourism education curricula (DNA, 2013; Singh, 2005).

The most desired competencies include communication skills, professional appearance, guest service skills, understanding of industry expectations, pride in self and ability to work with people to complete administrative tasks (Tesone\& Ricci, 2005).Problemsolving, self-management and interpersonal skills are considered as most important skills (Raybould\& Wilkins, 2005).

Computer skills, language skills, the ability to work in a team and take up the role of a leader and knowledge about the tourism and hospitality industry have a major impact on one's career success (Lertwannawit, Serirat \& Pholpantin, 2009). An enthusiastic, well educated, committed and well-trained workforce is important for the tourism industry (Jiang \& Tribe, 2009).

The purpose of tourism programmes is to prepare the students for a career in the tourism industry. However, the extent to which institutions actually deliver programmes which meet the aim varies significantly. The availability of regular teaching staff with qualification and experience in the area of tourism plays an important role in moulding right human resources for the tourism and hospitality sector (Thomas \&Jaykumar, 2012).

The relationship between tourism educators and tourism employers is important to meet the demands of the society and the needs of the students to create a curriculum that would best suit the authentic needs of all the stakeholders. A new innovative approach to tourism education is to establish links with the industry which will condiment the skill development of tourism scholars. A practical attachment in terms of theory oriented learning can help the students to accrue skills, and the practicing institution can benefit by way of increased output in meeting their target. Finally, the curriculum can benefit from up to date material which will contribute to knowledge creation. As a professional course, tourism education needs industry inputs. The tourism education structure should be a judicious mix of all the areas of functional management and must also include operational knowledge of different segments of the tourism and travel industry. Tourism education should offer students well-balanced 
curricula consisting of equal proportions of general business principles, liberal studies, and professional concepts. Quality education, industry-institute partnership, collaboration with consultants, are thinking of vocational education, higher education, research \& training in the field have to be incorporated for the smooth functioning of the tourism industry (Kumar, 2013; Thomas, 2007; Singh,2005; Sofique).

The various programmes and courses in tourism education have created confusion in the minds of stakeholders concerning what tourism programmes offer. Further, it will also create problems among graduate students in finding a job. There is a need to have clarity in the content and nature of tourism education. Employers often recruit non-tourism graduates who can contribute generic skills required by the industry because there is uncertainty among tourism employers, who are unrelated to tourism about the content and nature of tourism degrees (Dale \& Robinson, 2001).

In tourism education institutions, the students should be trained not only for entry level jobsbutlifelong careers as well. Hence career training must develop the ability to think creatively rather than merely performing certain routine tasks. The students of the tourism program must be broadly educated with awareness, knowledge, and skills with a professional specialization in tourism (Singh, 2005).

\section{Objectives}

The main objective of this study is to find out the gap between competency expectations of tourism students and tourism professionals.

\section{Scope of the Study}

The scope of the study covers institutions offering higher education in travel and tourism in Bangalore, Shimoga, and Mangalore, and Service providers such as Tour Operators, Travel Agents, Airlines and Hotels within Bangalore 


\section{Research Methodology}

\section{Data Collection}

Primary data is collected with the help of a structured questionnaire. Secondary data is collected by referring various books, journals and online sources such as EBSCO, ProQuest, Google Scholar, etc. and both primary and secondary data are usedfor the present study.

\section{Statistical Tools}

For the current study, the Researcher has used two tools namely:

Education Survey Questionnaire by Jie Wang (2008)

Industry Survey Questionnaire by Jie Wang (2008)

\section{Statistical Techniques}

Statistical techniques such as correlation and paired sample test are used to analyse the data.

\section{Hypothesis}

There is no significant relationship between perception of tourism academicians and tourism professionals towards skills and abilities imparted for employment in tourism industry

\section{Sample of the study}

The population defined for the present study involves tourism professionals working in travel agencies, tour operations, airlines and hotels and tourism faculty members in education institutions

\section{Data Analysis and Interpretation}

The data collected have been analysed using paired sample test and correlation by using SPSS 20 version statistical software and the results obtained thereby have been interpreted. The objective and hypothesis of the study were achieved by analysing the perception 
of tourism faculty members and tourism professionals on skills and abilities required to be employed in the tourism industry.

Table 1 Correlation between perception of tourism professionals and tourism academicians on skills and abilities imparted for employment in tourism industry

\begin{tabular}{|c|c|c|c|}
\hline \multicolumn{4}{|c|}{ Correlations } \\
\hline & & $\begin{array}{c}\text { Perception of } \\
\text { tourism } \\
\text { professionals on } \\
\text { skills and abilities }\end{array}$ & $\begin{array}{c}\text { Perception of } \\
\text { tourism } \\
\text { academicians on } \\
\text { skills and abilities }\end{array}$ \\
\hline \multirow{3}{*}{$\begin{array}{l}\text { Perception of } \\
\text { tourism } \\
\text { professionals } \\
\text { on skills and } \\
\text { abilities }\end{array}$} & $\begin{array}{l}\text { Pearson } \\
\text { Correlation }\end{array}$ & 1 & 0.040 \\
\hline & Sig. (2-tailed) & & .781 \\
\hline & $\mathrm{N}$ & 344 & 51 \\
\hline \multirow{3}{*}{$\begin{array}{l}\text { Perception of } \\
\text { tourism } \\
\text { academicians } \\
\text { on skills and } \\
\text { abilities }\end{array}$} & $\begin{array}{l}\text { Pearson } \\
\text { Correlation }\end{array}$ & 0.040 & 1 \\
\hline & Sig. (2-tailed) & .781 & \\
\hline & $\mathrm{N}$ & 51 & 51 \\
\hline
\end{tabular}

From the results of the above table, it can be seen that no significant relationship was observed between the perception of tourism professionals on skills and abilities and tourism academician's perception of skills and abilities and it is also proved through the $r$ value, (0.040) that the correlation between the variables is low. Hence, the null hypothesis is accepted.

To find out the difference between the perception of tourism professionals and tourism academicians towards skills and abilities, paired sample test has been applied 
Table 2 Paired Sample Test shows the perception towards individual skills and abilities between tourism academicians and tourism professionals

\begin{tabular}{|c|c|c|c|c|c|c|c|}
\hline \multirow[t]{2}{*}{ Skills and Abilities } & \multirow[t]{2}{*}{ Groups } & \multirow[t]{2}{*}{ Mean } & \multirow[t]{2}{*}{$\begin{array}{c}\text { Std. } \\
\text { Deviation }\end{array}$} & \multicolumn{2}{|c|}{$\begin{array}{l}95 \% \text { Confidence } \\
\text { Interval of the } \\
\text { Difference }\end{array}$} & \multirow[t]{2}{*}{$\mathrm{t}$} & \multirow[t]{2}{*}{$\begin{array}{l}\text { Sig. (2- } \\
\text { tailed) }\end{array}$} \\
\hline & & & & Lower & Upper & & \\
\hline Oral communication & $\begin{array}{l}\text { Tourism Academicians } \\
\text { Tourism Professionals }\end{array}$ & $\begin{array}{l}4.8039 \\
4.5686\end{array}$ & $\begin{array}{l}0.52989 \\
0.57463\end{array}$ & 0.01320 & 0.45738 & 2.128 & .038 \\
\hline Written communication & $\begin{array}{l}\text { Tourism Academicians } \\
\text { Tourism Professionals }\end{array}$ & $\begin{array}{l}4.8039 \\
4.4118\end{array}$ & $\begin{array}{l}0.52989 \\
0.57189\end{array}$ & 0.18873 & 0.59558 & 3.872 & .000 \\
\hline Leadership ability & $\begin{array}{l}\text { Tourism Academicians } \\
\text { Tourism Professionals }\end{array}$ & $\begin{array}{l}3.9804 \\
4.4902\end{array}$ & $\begin{array}{l}0.78715 \\
0.57871\end{array}$ & -0.78751 & -0.23210 & -3.687 & .001 \\
\hline Management skills & $\begin{array}{l}\text { Tourism Academicians } \\
\text { Tourism Professionals }\end{array}$ & $\begin{array}{l}4.4314 \\
4.5686\end{array}$ & $\begin{array}{l}0.50020 \\
0.50020\end{array}$ & -0.33227 & 0.05776 & -1.414 & .164 \\
\hline $\begin{array}{l}\text { Relationship } \\
\text { management skills }\end{array}$ & $\begin{array}{l}\text { Tourism Academicians } \\
\text { Tourism Professionals }\end{array}$ & $\begin{array}{l}4.6863 \\
4.7255\end{array}$ & $\begin{array}{l}0.46862 \\
0.45071\end{array}$ & -0.22545 & 0.14701 & -0.423 & .674 \\
\hline Adaptability at work & $\begin{array}{l}\text { Tourism Academicians } \\
\text { Tourism Professionals }\end{array}$ & $\begin{array}{l}4.4314 \\
4.5294\end{array}$ & $\begin{array}{l}0.64047 \\
0.50410\end{array}$ & -0.32483 & 0.12875 & -0.868 & .389 \\
\hline Confidence & $\begin{array}{l}\text { Tourism Academicians } \\
\text { Tourism Professionals }\end{array}$ & $\begin{array}{l}4.4902 \\
4.4902\end{array}$ & $\begin{array}{l}0.50488 \\
0.64413\end{array}$ & -0.22500 & 0.22500 & 0.000 & 1.000 \\
\hline
\end{tabular}




\begin{tabular}{|c|c|c|c|c|c|c|c|}
\hline Team working skills & $\begin{array}{l}\text { Tourism Academicians } \\
\text { Tourism Professionals }\end{array}$ & $\begin{array}{l}4.4902 \\
4.6471\end{array}$ & $\begin{array}{l}0.64413 \\
0.55941\end{array}$ & -0.37012 & 0.05639 & -1.477 & .146 \\
\hline Research skills & $\begin{array}{l}\text { Tourism Academicians } \\
\text { Tourism Professionals }\end{array}$ & $\begin{array}{l}4.4902 \\
3.7843\end{array}$ & $\begin{array}{l}0.50488 \\
1.20522\end{array}$ & 0.34006 & 1.07170 & 3.876 & .000 \\
\hline Creativity & $\begin{array}{l}\text { Tourism Academicians } \\
\text { Tourism Professionals }\end{array}$ & $\begin{array}{l}3.5882 \\
4.1961\end{array}$ & $\begin{array}{l}0.96284 \\
0.63308\end{array}$ & -0.94100 & -0.27469 & -3.665 & .001 \\
\hline Critical thinking & $\begin{array}{l}\text { Tourism Academicians } \\
\text { Tourism Professionals }\end{array}$ & $\begin{array}{l}4.1961 \\
4.0980\end{array}$ & $\begin{array}{l}0.56638 \\
0.94350\end{array}$ & -0.21644 & 0.41252 & 0.626 & .534 \\
\hline Decision making & $\begin{array}{l}\text { Tourism Academicians } \\
\text { Tourism Professionals }\end{array}$ & $\begin{array}{l}4.1765 \\
4.3529\end{array}$ & $\begin{array}{l}0.79261 \\
0.62685\end{array}$ & -0.43854 & 0.08560 & -1.353 & .182 \\
\hline Negotiation skills & $\begin{array}{l}\text { Tourism Academicians } \\
\text { Tourism Professionals }\end{array}$ & $\begin{array}{l}4.4902 \\
4.3922\end{array}$ & $\begin{array}{l}0.50488 \\
0.69508\end{array}$ & -0.15512 & 0.35120 & 0.778 & .440 \\
\hline Practical skills & $\begin{array}{l}\text { Tourism Academicians } \\
\text { Tourism Professionals }\end{array}$ & $\begin{array}{l}4.4314 \\
4.3333\end{array}$ & $\begin{array}{l}0.75511 \\
0.71181\end{array}$ & -0.16733 & 0.36340 & 0.742 & .462 \\
\hline Computer skills & $\begin{array}{l}\text { Tourism Academicians } \\
\text { Tourism Professionals }\end{array}$ & $\begin{array}{l}4.5490 \\
4.0784\end{array}$ & $\begin{array}{l}0.64230 \\
0.68828\end{array}$ & 0.21682 & 0.72436 & 3.725 & .000 \\
\hline Problem solving skills & $\begin{array}{l}\text { Tourism Academicians } \\
\text { Tourism Professionals }\end{array}$ & $\begin{array}{l}4.1373 \\
4.4706\end{array}$ & $\begin{array}{l}0.87223 \\
0.50410\end{array}$ & -0.63451 & -0.03216 & -2.223 & .031 \\
\hline $\begin{array}{l}\text { Marketing and sales } \\
\text { skills }\end{array}$ & $\begin{array}{l}\text { Tourism Academicians } \\
\text { Tourism Professionals }\end{array}$ & $\begin{array}{l}4.4706 \\
4.2549\end{array}$ & $\begin{array}{c}0.50410 \\
.71675\end{array}$ & -0.43854 & 0.08560 & -1.353 & .182 \\
\hline
\end{tabular}




\begin{tabular}{|c|c|c|c|c|c|c|c|}
\hline $\begin{array}{l}\text { Event management } \\
\text { skills }\end{array}$ & $\begin{array}{l}\text { Tourism Academicians } \\
\text { Tourism Professionals }\end{array}$ & $\begin{array}{l}4.4314 \\
4.2157\end{array}$ & $\begin{array}{l}0.57463 \\
0.67272\end{array}$ & -0.21137 & 0.40744 & 0.636 & .527 \\
\hline Organizational ability & $\begin{array}{l}\text { Tourism Academicians } \\
\text { Tourism Professionals }\end{array}$ & $\begin{array}{l}4.1176 \\
4.2745\end{array}$ & $\begin{array}{l}0.84017 \\
0.87358\end{array}$ & -0.08160 & 0.63062 & 1.548 & .128 \\
\hline Industry knowledge & $\begin{array}{l}\text { Tourism Academicians } \\
\text { Tourism Professionals }\end{array}$ & $\begin{array}{l}4.0000 \\
3.8824\end{array}$ & $\begin{array}{l}1.03923 \\
0.65260\end{array}$ & -0.51780 & 0.00800 & -1.947 & .057 \\
\hline Customer service skills & $\begin{array}{l}\text { Tourism Academicians } \\
\text { Tourism Professionals }\end{array}$ & $\begin{array}{l}4.1373 \\
4.5294\end{array}$ & $\begin{array}{l}0.63308 \\
0.50410\end{array}$ & -0.17919 & 0.21841 & 0.198 & .844 \\
\hline Networking ability & $\begin{array}{l}\text { Tourism Academicians } \\
\text { Tourism Professionals }\end{array}$ & $\begin{array}{l}4.5098 \\
4.2745\end{array}$ & $\begin{array}{l}0.50488 \\
0.72328\end{array}$ & -0.39132 & 0.07759 & -1.344 & .185 \\
\hline $\begin{array}{l}\text { Relevant work } \\
\text { experience }\end{array}$ & $\begin{array}{l}\text { Tourism Academicians } \\
\text { Tourism Professionals }\end{array}$ & $\begin{array}{l}4.4314 \\
4.0784\end{array}$ & $\begin{array}{l}0.50020 \\
0.59475\end{array}$ & -0.39515 & 0.12064 & -1.069 & .290 \\
\hline Academic grades & $\begin{array}{l}\text { Tourism Academicians } \\
\text { Tourism Professionals }\end{array}$ & $\begin{array}{l}4.2157 \\
3.6471\end{array}$ & $\begin{array}{l}0.61037 \\
0.74360\end{array}$ & -0.21839 & 0.37525 & 0.531 & .598 \\
\hline Work ethics & $\begin{array}{l}\text { Tourism Academicians } \\
\text { Tourism Professionals }\end{array}$ & $\begin{array}{l}3.5686 \\
3.3529\end{array}$ & $\begin{array}{l}0.87761 \\
0.82033\end{array}$ & -1.31820 & 0.68180 & -6.312 & .000 \\
\hline
\end{tabular}


From the above table it can be found that out of 25 skill sets,there is a statistical difference $(p$-value $<0.05)$ in the perception towards oral communication skills, written communication skills, leadership ability, research skills, creativity, computer skills, problem-solving skills, and work ethics between tourism academicians and tourism professionals.

\section{Findings of the Study}

According to the study, there is no significant relationship( $\mathrm{r}=0.040$, $p>0.781$ ) between the perception of tourism professionals and tourism academicians on skills and abilities imparted for employment in the tourism industry. There is a statistical difference $(p$-value $<0.05)$ in the perception towards oral communication skills, written communication skills, leadership ability, research skills, creativity, computer skills, problem-solving skills, and work ethics between tourism academicians and tourism professionals.

\section{Implications and Suggestions}

There is a difference between the perception of tourism professionals and academicians towards oral communication skills, written communication skills, leadership ability, research skill, creativity, computer skills, problem-solving skills, and work ethics. Educational institutions to reduce the gap, need to impart these skills and abilities to the students that will meet the expectations of the tourism industry.

\section{Conclusion}

The role of tourism in the national economy is proven without any doubt. All the sectors of the tourism industry such as travel agency, tour operations, airlines, and hotels play a significant role in transforming the economy of a nation. These organizations generate foreign exchange earnings and create employment opportunities, and at the same time, its development and growth depend on the human resources. These sectors rely more on the human resources for their day to day operations. Though 
technology plays a significant role in this sector, human capital is very much essential for the survival of the organization.

Tourism industry requires skilled workforce to meet the growing demands, and the development of a skilled workforce for the tourism industry is the responsibility of tourism education. Education institutions have to build skills and knowledge among human resources to meet the various diverse needs of an organization. The knowledge and skills are very much essential to perform tasks effectively in this sector. This study was conducted to check whether tourism education met the requirements and expectations of the tourism industry.

\section{Reference}

Dale, C., \& Robinson, N. (2001). The theming of tourism education: A three-domain approach. International Journal of Contemporary Hospitality Management,13 (1), 30-35. doi:10.1108/ 09596110110365616

Jiang, B., \& Tribe, J. (2009). Tourism jobs - short lived professions: Student attitudes towards tourism careers in China. The Journal of Hospitality Leisure Sport and Tourism JoHLSTE,8(1), 4-19. doi:10.3794/johlste.81.168

Jithendran, K. J., \& Baum, T. (2000). Human resources development and sustainability? The case of Indian tourism. International Journal of Tourism Research,2(6), 403-421. doi:10.1002/15221970(200011/12)2:63.0.co;2-3

Kumar, S. (2013). Tourism and hospitality education: Issues, challenges and opportunities in India. International Journal of Management Research and Review, 3(5), 2881-2889.

Kuruvilla, A., Moira, J. P., Mylonopoulos, D., Kuruvilla, A., \&Weng, R. (2011). Tourism curriculum in Greece and India - a comparative analysis. In 7th International Conference on Education (ICE) (Vol. A). Samos, Greece.

Lalnunmawia. (2013). Development and impact of the tourism industry in India. Retrieved from http://www.trcollege.net/articles/74development-and-impact-of-tourism-industry-in-India 
Lertwannawit, A., Serirat, S., \& Pholpantin, S. (2009). Career Competencies and Career Success of Thai employees in Tourism and Hospitality Sector. International Business and Economics Research Journal, 8(11), 65.

National Skill Development Corporation. (2009). Human Resources and Skill Requirements in the Tourism, Travel, Hospitality, and Trade Sector (2022) - A Report. Retrieved from http://www.nsdcindia.org/pdf/tourism.pdf

Raybould, M., \& Wilkins, H. (2005). Over qualified and under experienced: Turning Graduates into hospitality managers. International Journal of Contemporary Hospitality Management, $17(2 / 3)$.

Rege, P. (2013). Why is young India under skilled? Retrieved April

07, 2016, from http://www.dnaindia.com/academy/reportwhy-is-young-india-under-skilled-1904153

Singh, R. (2005). "Tourism curriculum designing for bridging the gap between industry and Education needs", in George,B.P.,andSwain,S.K. (Eds), Advancement in Tourism Theory and Practice: Perspective from India, Abhijeet Publications, Delhi.

Sofique, A. Tourism Education in India: Challenges and Opportunities in the Global context. Retrieved fromhttp://www.academia.edu/1882194/ Tourism education_in_India_Challenges_and_Opportunities_in_the_Glo bal_context

Tesone, D., \& Ricci, P. (2005). Toward a definition of entry-level job competencies: Hospitality manager perspectives. International Journal of Hospitality ETourism Administration, 7(4), 65-80.

Thomas, T.K. (2007). Issues in Effective Teaching Learning in Tourism Education. Atna Journal of Tourism Studies, 2, 101.

Thomas, J., \&Jaykumar, V. (2012). Sustainable and Dynamic Tourism and Hospitality Curriculum: An Analysis of Tourism Education in South India. Ripples, 88-95

Tourism education. (n.d.). Retrieved April 05, 2016, from http://www.attoi.org/tourismeducation.html

Wang, J. (2008). Is tourism education meeting the needs of the tourism industry? An Australian case study. Retrieved from 
http://www.canberra.edu.au/researchrepository/file/1d7eef3 8-6d47-552b-673e-adb17f0c721a/1/full_text.pdf

World Tourism Organization (2004). TedQual certification system. Volume I. Executive Introduction. Retrieved from http://www.themis.ad/english/ products/ portfolio/ tedqua Leng.pdf 